\title{
Hubungan Tingkat Pengetahuan dan Ketepatan Penggunaan Obat Simvastatin pada Pasien Hiperkolesterolemia di Apotek Kota Malang
}

\author{
Ayuk Lawuningtyas Hariadini ${ }^{1 *}$, Bambang Sidharta ${ }^{I}$, Tamara Gusti Ebtavanny ${ }^{I}$, Eka Putri Minanga $^{I}$ \\ ${ }^{1}$ Jurusan Farmasi, Fakultas Kedokteran Universitas Brawijaya, Malang, Indonesia
}

\section{INFO ARTIKEL}

Sejarah artikel:

Penerimaan naskah:

30 Desember 2019

Penerimaan naskah

revisi:

26 Maret 2020

Disetujui untuk

dipublikasikan:

02 Juni 2020

\section{Kata kunci :}

Pengetahuan,

Ketepatan, Simvastatin,

Hiperkolesterolemia

\begin{abstract}
A B S T R A K
Simvastatin adalah obat untuk menurunkan kadar Low Density Lipoprotein (LDL) dan Triglycerides (TG) yang harus diperoleh dengan resep dokter. Ketidaktepatan penggunaannya dapat berdampak kesalahan dalam pengobatan dan berisiko menimbulkan reaksi obat yang tidak dikehendaki (ROTD), yaitu pusing, tachycardia, dan aritmia. Penggunaan obat yang tidak tepat salah satunya disebabkan oleh informasi yang tidak lengkap atau tidak benar yang didapatkan pasien dimana akan berpengaruh pada tingkat pengetahuan pasien. Tujuan penelitian ini adalah untuk mengetahui hubungan antara tingkat pengetahuan dan ketepatan penggunaan obat simvastatin pada pasien hiperkolesterolemia di Apotek Kota Malang. Penelitian ini menggunakan metode penelitian observasional analitik dengan rancangan penelitian cross sectional yang telah dinyatakan laik etik oleh Komisi Etik Penelitian Kesehatan Fakultas Kedokteran Universitas Brawijaya dengan SK No. 136/EC/KEPK-S1-FARM/04/2019. Pemilihan sampel apotek dilakukan dengan teknik random sampling secara cluster sampling. Untuk pemilihan sampel responden digunakan teknik purposive sampling yaitu dipilih berdasarkan kriteria inklusi dan eksklusi. Pada penelitian ini subyek penelitian berjumlah 100 responden, analisis yang digunakan untuk mengetahui hubungan antara tingkat pengetahuan dan ketepatan penggunaan obat simvastatin adalah analisis korelasi somers' $d$. Didapatkan hasil penelitian responden yang memiliki tingkat pengetahuan baik cenderung lebih tepat dalam penggunaan simvastatin (tepat $=51,8 \%$, tidak tepat $=48,2 \%$ ) dibandingkan dengan responden yang memiliki pengetahuan yang cukup (tepat $=27,3 \%$, tidak tepat $=72,7 \%$ ) dan kurang $($ tepat $=16,7 \%$, tidak tepat $=83,3 \%$ ). Hasil analisis uji somers' $d$ menunjukkan $\mathrm{p}=0,000(\mathrm{p}<0,05)$ sehingga dapat disimpulkan bahwa terdapat hubungan positif yang signifikan antara tingkat pengetahuan dan ketepatan penggunaan obat simvastatin dan dari uji somers'd diketahui koefisien korelasi sebesar 0,287 sehingga keeratan hubungan adalah lemah tapi pasti antara tingkat pengetahuan dan ketepatan penggunaan obat simvastatin.
\end{abstract}

\section{Correlation between Hypercholesterolemic Patient's Knowledge and Simvastatin Use in Malang Retail Pharmacies}

\section{Keywords:}

Knowledge, Proper

Use, Simvastatin,

Hypercholesterolemi a

\begin{abstract}
A B S T R A C T
Simvastatin is a prescription medicine which used for lowering Low Density Lipoprotein (LDL) dan Triglycerides (TG). However, misuse of this drug might lead to an adverse drug reaction, such as dizziness, tachycardia, and aritmia. Improper use of drug might be caused by incomplete or invalid information obtained by patients which affects their level of knowledge. This research was conducted to examine the correlation between knowledge level and the proper use of simvastatin among patients with hypercholesterolaemia at pharmacies in Malang. This research was conducted in the form of analytical observational approach using the cross sectional design which has ethical clearance by the Medical Research Ethics Commission of the Faculty of Medicine, Universitas Brawijaya No. 136 / EC / KEPK-S1-FARM / 04/2019. Samples were randomly selected using the cluster sampling technique. Whereas, respondents were selected using a purposive sampling technique based on the predetermined inclusion and exclusion criteria. There were 100 respondents participated in this research. Somers'd correlation analysis was administered to examine the correlation between knowledge level and the proper use of simvastatin administration. The results of the study respondents who have a good level of knowledge tend to be more proper use of simvastatin (Proper $=51.8 \%$, improper $=48.2 \%$ ) compared to respondents who have average knowledge (proper $=27.3 \%$, improper $=72.7 \%$ ) and poor knowledge $($ proper $=16.7 \%$, improper $=83.3 \%)$. The results of the Somers'd analysis showed $p=0.000(p<0.05)$, which shows a positive and significant correlation between the two variables. Somers'd correlation analysis shows a correlation coefficient of 0.278 , there was a weak but definite correlation between knowledge level and the proper use of simvastatin.
\end{abstract}




\section{Pendahuluan}

Hiperkolesterolemia merupakan suatu gangguan yang ditandai dengan adanya peningkatan kadar kolesterol total darah lebih dari $240 \mathrm{mg} / \mathrm{dl}^{1}$. Peningkatan kadar kolesterol diatas normal dapat meningkatkan risiko terjadinya penyakit jantung dan cerebrovascular accident (CVA) yang membahayakan.

Secara global, sepertiga penyakit jantung iskemik disebabkan oleh hiperkolesterolemia. Menurut WHO tahun 2008, peningkatan total kolesterol tertinggi ada pada wilayah Eropa yaitu 54\% dan di ikuti wilayah Amerika yaitu $48 \%{ }^{2}$. Prevalensi hiperkolesterolemia di Indonesia berdasarkan laporan Riset Kesehatan Dasar (Riskesdas) 2013, didapatkan bahwa proporsi penduduk dengan kadar kolesterol di atas normal sebesar 39,6\% adalah perempuan dan 30\% adalah laki-laki, di lihat dari tempat tinggal, diperkotaan sebesar 39,5\% lebih tinggi dibandingkan dengan daerah diperdesaan yaitu sebesar $32,1 \%{ }^{3}$.

Faktor penyebab peningkatan kadar kolesterol dapat disebabkan karena faktor genetik dan faktor sekunder akibat dari penyakit lain ${ }^{4}$. Pasien hiperkolesterolemia disarankan untuk mengatur pola makan dan meningkatkan aktivitas fisik. Pada keadaan tertentu, diperlukan terapi farmakologi. Salah satu pilihan obat untuk penderita hiperkolesterolemia adalah obat golongan statin. Statin bekerja dengan cara menghambat enzim HMG-CoA reduktase dan merupakan obat pilihan yang efektif untuk menurunkan kolesterol LDL ${ }^{5}$.

Obat golongan statin yang biasa digunakan untuk pasien hiperkolesterolemia adalah simvastatin. Simvastatin merupakan golongan obat keras yang harus tepat dalam penggunaannya untuk menurunkan risiko efek samping dan meningkatkan efektivitas obat. Pemicu peningkatan risiko efek samping apabila obat digunakan secara tidak tepat seperti menggunakan obat simvastatin bersamaan dengan obat yang menghambat sitokrom p450-3A4 (CYP3A4), antibiotik makrolida ${ }^{6}$. Dosis simvastatin $80 \mathrm{mg}$ sehari juga meningkatkan risiko efek samping gangguan otot sehingga tidak dianjurkan untuk digunakan pada terapi awal kecuali pada pasien yang telah menggunakan dosis ini selama 12 bulan atau lebih tanpa bukti ganguan otot ${ }^{5}$.

Menurut World Health Organization (WHO) penggunaan obat yang tidak rasional sekitar 50\% disebabkan oleh peresepan, penyediaan, atau diberikan secara tidak tepat dan sekitar 50\% lainnya karena tidak digunakan secara tepat oleh pasien ${ }^{7}$. Apoteker di apotek sangat berperan dalam menjamin ketepatan penggunaan obat pada pasien untuk meminimalisir kejadian yang tidak di inginkan, yakni apoteker berperan dalam skrining permintaan obat, melakukan penyiapan obat, penyerahan dan pemberian informasi obat, konseling, monitoring dan evaluasi ${ }^{8}$. Penggunaan obat yang tidak tepat salah satunya dapat disebabkan akibat dari informasi yang tidak lengkap atau tidak benar'. Dalam Journal of Emergency Practice and Trauma dilaporkan seorang pasien laki-laki berusia 53 tahun terdiagnosis rabdomiolisis terkait dengan penggunaan statin. Pasien menggunakan $40 \mathrm{mg}$ atorvastatin untuk hiperlipidemia dan dosis tambahan 20 mg tablet yang diinisiasi sendiri tanpa anjuran dokter. Sebagai kesimpulan statin mengakibatkan efek samping yang fatal jika tidak digunakan dengan tepat ${ }^{10}$.

Berdasarkan uraian diatas, maka perlu dilakukan penelitian tentang hubungan antara tingkat pengetahuan dan ketepatan penggunaan obat simvastatin pada pasien hiperkolesterolemia di Apotek Kota Malang. Penelitian dilakukan di apotek karena apotek merupakan salah satu tempat praktek kefarmasian oleh apoteker dan sarana pelayanan kefarmasian di masyarakat.

\section{Metode}

Penelitian ini menggunakan metode penelitian observasional analitik dengan rancangan penelitian cross sectional yang dilaksanakan pada bulan September hingga bulan Oktober 2019 di apotek Kota Malang, besar sampel sebanyak 100 responden dihitung menggunakan rumus Lemeshow:

$$
\mathrm{n}=\frac{\mathrm{z}^{2} \cdot \mathrm{p} \cdot \mathrm{q}}{\mathrm{d}^{2}}
$$

Dengan ketetapan nilai $Z=1,96 ; P=0,5 ; d=0,1$ diperoleh jumlah sampel minimal sebanyak 96 responden yang dibulatkan menjadi 100 responden.

Pemilihan apotek menggunakan teknik cluster random sampling, dikelompokkan berdasarkan kecamatan di Kota Malang yaitu, kecamatan lowokwaru, klojen, blimbing, kedungkandang dan sukun. Untuk pemilihan responden sebagai subyek penelitian digunakan teknik purposive sampling dipilih berdasarkan kriteria inklusi dan eksklusi. Kriteria inklusi pada penelitian ini adalah pasien yang datang ke apotek kota Malang, terdiagnosis hiperkolesterolemia, pasien yang mendapatkan resep obat simvastatin, menggunakan simvastatin minimal 1 bulan dan pasien yang berusia $\geq 20$ tahun.

Instrumen penelitian berupa kuesioner yang dirancang oleh peneliti dan telah diuji validitas serta realibilitasnya. Kuesoner berjumlah 16 butir yang dibagi menjadi 2 bagian, yaitu kuisoner untuk mengukur tingkat pengetahuan dan ketepatan penggunaan obat simvastatin. Pernyataan pada kuesioner berbentuk tertutup dengan pilihan jawaban benar dan salah.

Sebelum dianalisis, dilakukan uji normalitas data menggunakan metode kolmogorov-smirnov. Hasil uji 
normalitas data menyatakan bahwa data tidak berdistribusi normal. Oleh karena itu, hubungan antara tingkat pengetahuan pasien dengan ketepatan penggunaan obat simvastatin dianalisis menggunakan uji korelasi somers'd.

\section{Hasil dan Diskusi}

Jumlah responden pada penelitian ini adalah 100 pasien untuk 5 kecamatan, dengan jumlah responden pada masing-masing kecamatan adalah sebagai berikut.

Tabel 1. Jumlah Responden Dimasing-masing Kecamatan Kota Malang

\begin{tabular}{clc}
\hline No. & $\begin{array}{l}\text { Kecamatan di Kota } \\
\text { Malang }\end{array}$ & Jumlah Responden \\
\hline $\mathbf{1}$ & Kecamatan Klojen & 20 pasien \\
\hline $\mathbf{2}$ & Kecamatan Sukun & 20 pasien \\
\hline $\mathbf{3}$ & $\begin{array}{l}\text { Kecamatan } \\
\text { Kedungkandang }\end{array}$ & 20 pasien \\
\hline $\mathbf{4}$ & Kecamatan Lowokwaru & 20 pasien \\
\hline $\mathbf{5}$ & Kecamatan Blimbing & 20 pasien \\
\hline
\end{tabular}

Pada penelitian yang dilakukan, diperoleh data demografi yaitu, usia, pendidikan dan pekerjaan.

Tabel 2. Data Demografi Responden

\begin{tabular}{lcc}
\hline Demografi & Jumlah & $\%$ \\
\hline Usia & & \\
\hline $31-40$ & 1 & 1 \\
\hline $41-50$ & 41 & 41 \\
\hline $51-60$ & 50 & 50 \\
\hline$>60$ & & \\
\hline Pendidikan & 11 & 11 \\
\hline SD & 11 & 11 \\
\hline SLTP & 37 & 37 \\
\hline SLTA & 41 & 41 \\
\hline Perguruan Tinggi & & \\
\hline Pekerjaan & 21 & 21 \\
\hline Ibu Rumah Tangga & 5 & 5 \\
\hline Swasta & 11 & 11 \\
\hline PNS & 17 & 17 \\
\hline Wiraswasta & 46 & 46 \\
\hline Pensiunan & & \\
\hline
\end{tabular}

Pekerjaan responden yang terbanyak adalah pensiunan, 46 responden $(46 \%)$ dan yang menggunakan obat simvastatin paling banyak terdapat pada usia > 60 tahun yaitu sebanyak 50 responden $(50 \%)$ dan paling sedikit pada rentang usia 31-40 tahun yaitu hanya 1 responden (1\%). Ada beberapa faktor yang dapat menyebabkan hiperkolesterolemia salah satunya adalah faktor usia. Semakin bertambahnya usia fungsi reseptor LDL akan menurun sehingga dapat menyebabkan peningkatan kadar LDL didalam darah ${ }^{11}$. Selain itu wanita yang telah memasuki masa menopause juga terbukti mengalami risiko peningkatan kolesterol karena adanya penurunan hormon estrogen yang berfungsi mengendalikan kadar kolesterol ${ }^{12}$. Tingkat pendidikan terbanyak adalah perguruan tinggi sejumlah 41 responden (41\%). Pendidikan memiliki pengaruh pada tingkat kemampuan berpikir, dengan kata lain seseorang dengan pendidikan lebih tinggi akan dapat mengambil keputusan yang lebih rasional. Semakin tinggi pendidikan seseorang, semakin tinggi pula ia menerima informasi dan besar pengaruhnya terhadap perubahan perilaku yang lebih baik $^{13}$.

Tabel 3 memuat karakteristik responden yang lain, yaitu lama penggunaan simvastatin, efek samping simvastatin yang pernah dialami, dan dosis simvastatin yang digunakan.

Tabel 3. Karakteristik Responden terkait Pengobatan Simvastatin

\begin{tabular}{lcc}
\hline Lama Penggunaan Simvastatin & Jumlah & $\%$ \\
\hline $1-3$ bulan & 43 & 43 \\
\hline $4-6$ bulan & 8 & 8 \\
\hline $10-12$ bulan & 1 & 1 \\
\hline$\geq 1$ tahun & 48 & 48 \\
\hline Efek Samping & 1 & 1 \\
\hline Nyeri Perut & 12 & 12 \\
\hline Kembung & 87 & 87 \\
\hline Tidak Mengalami Efek Samping & & \\
\hline Dosis Simvastatin yang Digunakan & 15 & 15 \\
\hline 5 mg & 45 & 45 \\
\hline 10 mg & 39 & 39 \\
\hline 20 mg & 1 & 1 \\
\hline 40 mg & & \\
\hline
\end{tabular}


Lama penggunaan obat simvastatin paling banyak adalah penggunaan selama $\geq 1$ tahun, sejumlah 48 responden (48\%). Simvastatin adalah obat yang efektif terutama dalam menurunkan kolesterol LDL biasanya digunakan dalam jangka panjang untuk mencegah kembalinya peningkatan kadar kolesterol. Statin memiliki manfaat mortalitas dan morbiditas yang signifikan untuk pencegahan primer dan sekunder dari penyakit kardiovaskular $^{14}$.

Pada efek samping, Ada 12 responden (12\%) yang mengalami kembung dan 1 responden (1\%) yang mengalami nyeri perut. Dari 100 responden ada 87 responden $(87 \%)$ yang tidak mengalami efek samping. Pada hasil data tidak ada responden yang mengalami nyeri otot. Efek samping simvastatin atau golongan statin biasanya dikaitkan dengan gangguan otot, mekanisme statin mempengaruhi kinerja otot tidak sepenuhnya dipahami. Ada satu teori menjelaskan bahwa statin dapat menurunkan kadar koenzim Q10 dalam tubuh. Adanya inhibisi enzim HMG CoA menyebabkan penurunan produksi mevalonat. Mevalonat berperan dalam biosintesis kolesterol selain itu mevalonat juga berperan dalam biosintesis ubikuinon atau koenzim Q10 ${ }^{15}$. Koenzim Q10 adalah faktor penting dalam respirasi mitokondria, jika koenzim Q10 menurun maka akan berpengaruh terhadap otot $^{16}$.

Berdasarkan jurnal Acta Cardiologica Sinica dengan judul Statin Therapy: Review of Safety and Potential Side Effects menyatakan bahwa obat golongan statin sebenarnya aman untuk digunakan pada sebagian besar pasien. Namun, pasien dengan komorbiditas medis multipel berisiko lebih tinggi terhadap efek samping pada penggunaan statin jangka panjang ${ }^{14}$. BMJ Case Reports dengan judul Possible association between statin use and bowel dysmotility juga menyatakan bahwa statin dapat mempengaruhi kadar nitric oxide melalui peningkatan regulasi nitric oxide synthase. Beberapa bukti yang menyiratkan bahwa nitric oxide bekerja pada saraf di usus besar yang mengakibatkan dismotilitas usus. Dismotilitas ini dapat menimbulkan rasa tidak nyaman pada perut ${ }^{17}$.

Pada hasil penelitian, ada 12 responden (12\%) yang mengalami efek samping kembung dan ada 1 responden $(1 \%)$ yang mengalami nyeri perut. Responden yang mengalami efek samping menyampaikan bahwa sesekali merasakan hal yang sama atau berulang yaitu tidak nyaman pada perut setelah beberapa saat mengkonsumsi obat simvastatin, oleh karena itu dari hasil penelitian rasa kembung dan nyeri pada perut yang dirasakan oleh responden adalah memang merupakan efek samping dari simvastatin. Berdasarkan jurnal Fernandes et al, 2012, ada sebanyak 20\%-40\% laporan efek samping terkait rasa tidak nyaman pada perut.

Simvastatin dosis $10 \mathrm{mg}$ adalah yang paling banyak digunakan oleh responden yaitu sejumlah 45 responden $(45 \%)$. Pada hiperkolesterolemia kisaran dosis simvastatin yang biasa adalah 5 hingga $40 \mathrm{mg} /$ hari. Dosis awal yang dianjurkan adalah 10 atau $20 \mathrm{mg}$ sekali sehari di malam hari ${ }^{18}$.

Berikut adalah kuesioner yang digunakan sebagai alat ukur tingkat pengetahuan pasien:

Tabel 4. Kuesioner Pengetahuan

\begin{tabular}{|c|c|c|}
\hline No. & Pernyataan & Indikator \\
\hline 1. & $\begin{array}{l}\text { Penyakit Hiperlipidemia adalah suatu } \\
\text { kondisi meningkatnya konsentrasi } \\
\text { kolesterol dalam darah }\end{array}$ & Definisi \\
\hline 2. & $\begin{array}{l}\text { Hiperkolesterolemia dapat disebabkan } \\
\text { karena asupan lemak jenuh yang } \\
\text { berlebih }\end{array}$ & Etiologi \\
\hline 3. & $\begin{array}{l}\text { Hiperkolesterolemia juga dapat } \\
\text { disebabkan oleh faktor keturunan dari } \\
\text { keluarga }\end{array}$ & Etiologi \\
\hline 4. & $\begin{array}{l}\text { Simvastatin adalah obat yang berfungsi } \\
\text { untuk membantu menurunkan lemak } \\
\text { jahat atau Low Density Lipoprotein } \\
\text { (LDL) }\end{array}$ & Indikasi \\
\hline 5. & $\begin{array}{l}\text { Simvastatin harus diminum sehari satu } \\
\text { kali satu tablet }\end{array}$ & Dosis Obat \\
\hline 6. & $\begin{array}{l}\text { Simvastatin sebaiknya diminum pada } \\
\text { malam hari }\end{array}$ & Aturan Pakai \\
\hline 7. & $\begin{array}{l}\text { Penggunaan obat simvastatin dapat } \\
\text { dihentikan jika sudah merasa sehat atau } \\
\text { gejala seperti nyeri pada belakang } \\
\text { kepala sudah hilang tanpa perlu kembali } \\
\text { memeriksakan diri ke dokter }\end{array}$ & Lama Pemberian \\
\hline 8. & $\begin{array}{l}\text { Jika simvastatin dikombinasi dengan } \\
\text { semua jenis obat penurun kolesterol lain } \\
\text { maka akan memperbesar efek penurunan } \\
\text { kolesterol dalam tubuh }\end{array}$ & Cara Pemberian \\
\hline 9. & $\begin{array}{l}\text { Simvastatin dapat menimbulkan efek } \\
\text { samping nyeri otot }\end{array}$ & Efek Samping \\
\hline 10. & $\begin{array}{l}\text { Simvastatin harus disimpan pada suhu } \\
\text { ruangan atau sesuai dengan suhu yang } \\
\text { tercantum pada kemasan obat dan dalam } \\
\text { wadah yang terhindar dari cahaya } \\
\text { matahari }\end{array}$ & Penyimpanan \\
\hline
\end{tabular}

Kategori tingkat pengetahuan responden tertinggi adalah baik dengan persentase sebanyak $83 \%$ (83 responden) dan diikuti oleh tingkat pengetahuan yang cukup $11 \%$ (11 responden) dan yang paling sedikit adalah tingkat pengetahuan yang kurang 6\% (6 responden). Dari hasil tersebut menunjukkan bahwa sebagian besar responden memiliki tingkat pengetahuan yang baik.

Pengetahuan yang mayoritas belum diketahui oleh responden adalah mengenai etiologi faktor keturunan dan efek samping. Keduanya hanya dijawab benar oleh $39 \%$ responden.

Berikut adalah kuesioner yang digunakan sebagai alat ukur ketepatan penggunaan obat simvastatin oleh 
pasien:

Tabel 5. Kuesioner Ketepatan Penggunaan Obat

\begin{tabular}{|c|c|c|}
\hline No. & Pertanyaan & Indikator \\
\hline 1. & $\begin{array}{l}\text { Apakah Bapak/Ibu menggunakan } \\
\text { obat simvastatin sesuai dengan } \\
\text { dosis yang dianjurkan } \\
\text { dokter/apoteker? }\end{array}$ & Tepat Dosis \\
\hline 2. & $\begin{array}{l}\text { Apakah Bapak/Ibu menggunakan } \\
\text { obat simvastatin pada malam hari } \\
\text { ? }\end{array}$ & $\begin{array}{c}\text { Tepat Aturan } \\
\text { Pakai }\end{array}$ \\
\hline 3. & $\begin{array}{l}\text { Apakah Bapak/Ibu pernah } \\
\text { menghentikan penggunaan obat } \\
\text { simvastatin karena sudah merasa } \\
\text { sehat tanpa perlu memeriksakan } \\
\text { diri lagi ke dokter? }\end{array}$ & $\begin{array}{l}\text { Tepat Lama } \\
\text { Pemberian }\end{array}$ \\
\hline 4. & $\begin{array}{l}\text { Apakah Bapak/Ibu pernah } \\
\text { menggunakan obat simvastatin } \\
\text { bersamaan dengan obat penurun } \\
\text { kolesterol lain? }\end{array}$ & $\begin{array}{l}\text { Tepat Cara } \\
\text { Pemberian }\end{array}$ \\
\hline 5. & $\begin{array}{l}\text { Apakah Bapak/Ibu } \\
\text { memberitahukan kepada } \\
\text { dokter/apoteker jika mengalami } \\
\text { efek samping nyeri otot misalnya, } \\
\text { di tangan/kaki selama } \\
\text { menggunakan obat simvastatin? }\end{array}$ & $\begin{array}{c}\text { Waspada Efek } \\
\text { Samping }\end{array}$ \\
\hline 6. & $\begin{array}{l}\text { Apakah Bapak/Ibu menyimpan } \\
\text { obat simvastatin pada suhu } \\
\text { ruangan atau sesuai dengan suhu } \\
\text { yang tercantum pada kemasan } \\
\text { obat dan dalam wadah yang } \\
\text { terhindar dari cahaya matahari? }\end{array}$ & $\begin{array}{c}\text { Tepat Cara } \\
\text { Penyimpanan }\end{array}$ \\
\hline
\end{tabular}

Tabel 5 menunjukkan bahwa lebih banyak responden yang tidak tepat dalam penggunaan obat simvastatin yaitu sebanyak 53 responden (53\%) dan yang tepat dalam penggunaan obat simvastatin yaitu sebanyak 47 responden $(47 \%)$.

Perilaku yang mayoritas belum dilakukan oleh responden adalah mengenai lama pemberian obat. Responden yang menggunakan obat simvastatin dengan tepat lama pemberian hanya sebesar 51\%. Responden mengaku terkadang jenuh menggunakan obat simvastatin yang terlalu lama sehingga sesekali menghentikan pengobatan, ada juga yang menjelaskan bahwa pernah menghentikan obat karena sudah merasa tidak ada keluhan tanpa kembali memeriksakan diri kedokter meskipun beberapa dari responden sudah mengetahui jika penghentian obat tanpa kembali memeriksakan diri kedokter adalah salah. Apoteker memegang peranan dalam permasalahan ini. Apoteker harus menjalankan praktik sesuai standar pelayanan, salah satunya adalah pemberian Pelayanan Informasi Obat (PIO). Salah satu kegiatan Pelayanan Informasi Obat di Apotek adalah memberikan informasi dan edukasi kepada pasien. Adanya informasi dan edukasi akan meningkatkan pengetahuan dan kesadaran pasien sehingga terjadi perubahan perilaku dalam penggunaan Obat dan menyelesaikan masalah yang dihadapi pasien ${ }^{19}$.

Tabel 6. Tabulasi Silang

\begin{tabular}{cccc}
\hline \multirow{2}{*}{$\begin{array}{c}\text { Tingkat } \\
\text { Pengetahuan }\end{array}$} & \multicolumn{2}{c}{ Ketepatan Penggunaan Obat Simvastatin } \\
\cline { 2 - 4 } & Tepat & $\begin{array}{c}\text { Tidak } \\
\text { Tepat }\end{array}$ & Total \\
\hline Baik & $43(51,8 \%)$ & $40(48,2 \%)$ & $83(100 \%)$ \\
\hline Cukup & $3(27,3 \%)$ & $8(72,7 \%)$ & $11(100 \%)$ \\
\hline Kurang & $1(16,7 \%)$ & $5(83,3 \%)$ & $6(100 \%)$ \\
\hline
\end{tabular}

Pada tabel 6 diketahui hasil tabulasi silang antara tingkat pengetahuan dan ketepatan penggunaan obat simvastatin. Hasil menunjukkan responden yang memiliki tingkat pengetahuan baik lebih banyak yang tepat yaitu, sebanyak 43 responden $(51,8 \%)$ dibandingkan dengan yang tidak tepat yaitu, sebanyak 40 responden (48,2\%). Pada tingkat pengetahuan cukup lebih banyak responden yang tidak tepat yaitu, sebanyak 8 responden $(72,7 \%)$ dibandingkan dengan yang tepat yaitu, sebanyak 3 responden $(27,3 \%)$. Pada tingkat pengetahuan kurang juga lebih banyak yang tidak tepat yaitu, 5 responden $(83,3 \%)$ dibandingan dengan yang tepat yaitu ada 1 responden $(16,7 \%)$. Dari hasil data menunjukkan bahwa responden yang memiliki tingkat pengetahuan baik cenderung lebih tepat dalam penggunaan obat dibandingkan dengan responden yang memiliki pengetahuan cukup dan kurang.

Tabel 7. Uji Normalitas

\begin{tabular}{lcc}
\hline \multicolumn{1}{c}{ Variabel } & $\begin{array}{c}\text { p } \\
\text { value }\end{array}$ & Keterangan \\
\hline $\begin{array}{l}\text { Tingkat Pengetahuan } \\
\text { dan Ketepatan }\end{array}$ & 0,000 & $\begin{array}{c}\text { Berdistribusi tidak } \\
\text { normal }\end{array}$ \\
\hline
\end{tabular}

Uji normalitas menggunakan Kolmogorovsmirnov dan menunjukkan data berdistribusi tidak normal karena signifikansi sebesar 0,000 yaitu lebih kecil dari 0,05 sehingga uji yang digunakan adalah uji korelasi Somers'd. Uji korelasi Somers'd dilakukan untuk mengetahui adanya hubungan yang berikatan maupun tidak berikatan antar variabel terikat yaitu ketepatan penggunaan obat simvastatin dengan variabel bebas yaitu tingkat pengetahuan.

Tabel 8. Uji Korelasi Tingkat Pengetahuan dan Ketepatan 


\begin{tabular}{lcc}
\hline Variabel & Signifikansi & $\begin{array}{c}\text { Koefisien } \\
\text { Korelasi }\end{array}$ \\
\hline $\begin{array}{l}\text { Tingkat Pengetahuan } \\
\text { dan Ketepatan }\end{array}$ & 0,000 & 0,287 \\
\hline
\end{tabular}

Untuk melihat hubungan tingkat pengetahuan dan ketepatan penggunaan obat simvastatin pada pasien hiperkolesterolemia di Apotek Kota Malang dilakukan uji korelasi somers'd. Variabel dikatakan memiliki hubungan jika nilai $p$-value < koefisien alpha sebesar 0,05. Dari hasil analisis somers'd yang telah dilakukan diperoleh $p$ value sebesar 0,000 dimana hasilnya kurang dari 0,05 sehingga terdapat hubungan yang signifikan antara tingkat pengetahuan dan ketepatan penggunaan obat simvastatin. Berdasarkan tingkat keeratan korelasi dari kedua variabel, didapatkan hasil 0,287 yang berarti keeratan hubungan termasuk kedalam korelasi lemah tapi pasti. Dikatakan lemah tapi pasti jika nilai koefisien korelasi berada dalam rentang $0,20<\operatorname{IrI} \leq 0,40$. Tingkat pengetahuan merupakan salah satu faktor yang dapat mempengaruhi ketepatan penggunaan obat dimana semakin baik tingkat pengetahuan maka dapat meningkatkan perilaku untuk tepat dalam menggunakan obat. Sesuai dengan pernyataan Sunaryo (2002), bahwa pengetahuan merupakan salah satu faktor penting yang dapat membentuk suatu perilaku ${ }^{20}$.

\section{Daftar Pustaka}

1. Ehrman JK., Gordon PM., Visich PS., Keteyian SJ., 2009. Clinical Exercise Physiology, $2^{\text {nd }}$ Ed., Human Kinetics, USA, p.251.

2. WHO. 2019. Raised Cholesterol, (Online), (https://www.who.int/gho/ncd/risk_factors/cholester ol_text/en/, diakses pada tanggal 27 Januari 2019).

3. Kementerian Kesehatan RI. 2013.Riset Kesehatan Dasar, Jakarta, hal. 259.

4. Rubenstein D., Wayne D., Bradley J., Lecture Notes on Clinical Medicine, 2003, Lecture Notes: Kedokteran Klinis, Annisa Rahmalia (Penerjemah), 2007, Erlangga, Jakarta, Indonesia, hal. 192.

5. Perhimpunan Dokter Spesialis Kardiovaskular Indonesia. 2013. Pedoman Tatalaksana Dislipidemia. Centra Communication, hal.27-28.

6. Ezad S., Cheema H., Collins N. Statin-induced Rhabdomyolysis: a Complication of a Commonly Overlooked Drug Interaction. Oxford Medical Case Reports, 2018, (3).

7. WHO. 2002. Promoting Rational Use of Medicines : Core Components, WHO Policy Prespectives on Medicines. Geneva, p.1-6.

8. Kementerian Kesehatan RI. 2011. Modul Penggunaan Obat Rasional, Jakarta, hal. 3-7.

9. Kementerian Kesehatan RI.2006. Kebijakan Obat Nasional Menteri Kesehatan Republik Indonesia, Jakarta, hal 16.

10. Bolatkale M., Işsever M., Karaoğlu U., Acara AC., Bulut M. Heart Attack Or Rhabdomyolysis?.
Journal of Emergency Practice and Trauma, 2018, 4 (1): 51-52.

11. Ericsson S., Eriksson M., Vitols S., Einarsson K., Berglund L., Angelin B., 1991. Influence of age on the metabolism of plasma low density lipoproteins in healthy males. (Abstract). J Clin Invest, 87 (2): 591-596.

12. Marhoum T.A., Abdrabo A.A., Lutfi M.F. Effects of age and gender on serum lipid profile in over 55 years-old apparently healthy Sudanese individuals. Asian Journal of Biomedical and Pharmaceutical Sciences, 2013, 3 (19): 10-14.

13. Astutik RY. dan Ertiana D. 2018. Anemia Dalam Kehamilan. Edisi 1, Pustaka Abadi, Jember.

14. Ramkumar S., Raghunath A., Raghunath S. Statin Therapy: Review of Safety and Potential Side Effects. Acta Cardiol Sin, 2016, 32 (6): 631-639.

15. Tomlinson S.S., Mangione K.K. Potential Adverse Effects of Statins on Muscle. American Physical Therapy Association, 2005, 85 (5): 459-465.

16. Deichmann R., Lavie C., Andrews S. Coenzyme Q10 and Statin-Induced Mitochondrial Dysfunction. The Ochsner Journal, 2010, 10 (1): 16-21.

17. Fernandes R., Shaikh I., Wegstapel H. Possible association between statin use and bowel dysmotility. BMJ Case Reports, 2012.

18. Zodda D., Giammona R., Schifilliti S. Treatment Strategy for Dyslipidemia in Cardiovascular Disease Prevention: Focus on Old and New Drugs. Journal Pharmacy, 2018, 6 (10): 1-16.

19. Kementerian Kesehatan RI, 2016. Standar Pelayanan Kefarmasian di Apotek.

20. Sunaryo. 2002. Psikologi Untuk Keperawatan. Penerbit Buku Kedokteran EGC, Jakarta. 